\title{
ESTIMATION OF AMLODIPINE BESYLATE AND IRBESARTAN IN PHARMACEUTICAL FORMULATION BY RP-HPLC WITH FORCED DEGRADATION STUDIES
}

\author{
T. HEMANT KUMAR ${ }^{*}$, C. H. ASHA ${ }^{1}$, D. GOWRI SANKAR ${ }^{2}$
}

1Vignan Institute of Pharmaceutical Technology, Duvvada, Vishakapatnam, Andhra Pradesh, India, ${ }^{2}$ College of Pharmaceutical Sciences,
Andhra University, Andhra Pradesh, India

Received: 30 Aug 2018, Revised and Accepted: 28 Mar 2018

\begin{abstract}
Objective: To develop and validate a simple, specific, accurate, precise and sensitive reverse phase high performance liquid chromatographic (RP-HPLC) method with forced degradation studies for the simultaneous estimation of amlodipine besylate and irbesartan in the pharmaceutical formulation.

Methods: The chromatographic separation of the two drugs were achieved using Enable C 18G column $(250 \times 4.6 \mathrm{~mm}$; $5 \mu \mathrm{m})$ in isocratic mode with mobile phase consisting of sodium acetate buffer ( $\mathrm{pH} 4.0)$ and acetonitrile (30:70, \% v/v) with a flow rate of $0.6 \mathrm{ml} / \mathrm{min}$. Ultraviolet(UV) detection was carried out at $238 \mathrm{~nm}$. The proposed method was validated for linearity, range, accuracy, precision, robustness, limit of detection (LOD) and limit of quantification (LOQ). The tablet formulation was subjected to stress conditions of degradation including acidic, alkaline, oxidative, thermal and photolysis.

Results: The retention time for amlodipine besylate and irbesartan were found to be 5.512 and 6.321 min respectively. Linearity was observed over a concentration range $4-32 \mu \mathrm{g} / \mathrm{ml}$ for amlodipine besylate $\left(\mathrm{r}^{2}=0.9999\right)$ and $10-70 \mu \mathrm{g} / \mathrm{ml}$ for Irbesartan ( $\left.\mathrm{r}^{2}=0.9998\right)$. The $\%$ relative standard deviation (RSD) for Intraday and Interday precision was found to be 0.436 and 0.699 for amlodipine besylate and 0.435 and 0.30 for irbesartan. Amlodipine besylate shown stability towards acidic and thermal whereas in basic, oxidative and photolytic it shown less stability in which it degraded to more extent. Irbesartan shown stability towards thermal conditions whereas in remaining conditions it degrades to more extent especially in oxidative conditions.
\end{abstract}

Conclusion: The developed reverse phase high performance liquid chromatographic (RP-HPLC) method was also found to be simple, precise and sensitive for the simultaneous determination of amlodipine besylate and irbesartan in the tablet dosage form.

Keywords: Amlodipine Besylate, Irbesartan, RP-HPLC and Forced Degradation

(c) 2019 The Authors. Published by Innovare Academic Sciences Pvt Ltd. This is an open-access article under the CC BY license (http://creativecommons.org/licenses/by/4.0/) DOI: http://dx.doi.org/10.22159/ijap.2019v11i3.29426

\section{INTRODUCTION}

Amlodipine besylate (fig. 1), chemically designated as 2-[(2aminoethoxy)-methyl]-4-(2-chlorophenyl) 1,4-dihydro-6-methyl-3,5pyridine-dicarboxylic acid-3 ethyl-5 methyl ester, is a calcium channel blocker used to treat hypertension and angina. The drug is found to metabolize in the liver and the produced metabolites are excreted via urine along with some unchanged drug. Literature survey reveal various analytical method are reported either alone or combination with other drugs includes UV spectrophotometric[1-4], Visible spectrophotometric [5-7], spectrofluorometric [8], Titrimetry [5], LCMS [9], HPLC $[10,11]$ in pure drug, pharmaceutical formulations and biological fluids.

Irbesartan (fig. 2) is an angiotensin II receptor antagonist used in the management of hypertension including treatment of renal disease in hypertensive type II diabetic patients. It possesses an acidic tetrazole system and biphenyl system, does not have acidic side chain and even so it has good affinity for angiotensin II receptor because of hydrogen bonding with the carbonyl moiety of amide system. It decreases afterload and preload. It is more effective in providing $24 \mathrm{hr}$ control of blood pressure. Combination therapy of hypertension with different categories offers the potential to lower blood pressure more quickly, obtain target blood pressure, and decrease adverse effects. The combination tablet containing amlodipine $10 \mathrm{mg}$ and irbesartan $100 \mathrm{mg}$ had a greater BP-lowering effect than an angiotensin receptor blocker (ARB) and a low-dose or regular-dose calcium channel blocker (CCB). In addition, the combination tablet had more favorable effects on serum uric acid, low-density lipoprotein cholesterol, and high-density lipoprotein cholesterol levels in patients with hypertension [12]. Several analytical methods have been reported for the determination of Irbesartan either alone or in combination with other drugs in pure drug, pharmaceutical dosage forms and in biological samples using spectrophotometry [13-16], HPLC [17-39], HPTLC [40-42], LC-MS [43-45], and voltammetry [46] for the determination of irbesartan in pharmaceutical dosage forms. The combination of amlodipine besylate and irbesartan is effective in the treatment of hypertention. Various analytical methods were reported for simultaneous estimation of amlodipine besylate and irbesartan in pure drug, pharmaceutical formulations and biological fluids by HPLC [47-49]. Only one stability indicating RP-HPLC method was reported for the simultaneous estimation of both drugs in pharmaceutical formulation but the developed method has long retention time and low linearity range for both drugs. Therefore in the present study, an attempt was made to develop a simple, precise, accurate RP-HPLC method with forced degradation studies for the analysis of amlodipine besylate and irbesartan in pharmaceutical formulation.<smiles>CCOC(=O)C1=C(COCCN)NC(C)=C(C(=O)OC)C1c1ccccc1Cl</smiles>

Fig. 1: Structure of amlodipine besylate<smiles>CCCCC1=NC2(CCCC2)C(=O)N1Cc1ccc(-c2ccccc2-c2nn[nH]n2)cc1</smiles>

Fig. 2: Structure of Irbesartan 


\section{MATERIALS AND METHODS}

\section{Materials and chemicals}

Amlodipine Besylate and Irbesartan standard were obtained as gifted sample from pharma industry. Amlodipine Besylate and Irbesartan Tablets (AMIX R TABLETS) containing Irbesartan $100 \mathrm{mg}$ and amlodipine $10 \mathrm{mg}$ were purchased from a local pharmacy. HPLC grade Acetonitrile and water were from MERCK India Ltd. HPLC grade methanol was from standard reagent pvt ltd Hyderabad. Analytical grade acetic acid, sodium acetate, hydrochloric acid, sodium hydroxide and hydrogen peroxide were from SD Fine chemicals Mumbai, India. Nylon membrane filters $0.2 \mu \mathrm{m}$ and 0.45 $\mu \mathrm{m}$ were from PALL life sciences Mumbai India. Ultrasonicator used was from LAB india Ltd Mumbai. $\mathrm{p}^{\mathrm{H}}$ meter was of Elico LI 120 make. UV spectrophotometer was of Elico SL 210 model consisted of spectral treats software.

\section{Instrumentation}

The chromatographic system used for the method development and validation consisted of Shimadzu HPLC comprising of LC-20AD binary gradient pump, a variable wavelength programmable SPD$20 \mathrm{~A}$ detector and an SCL 20A system controller. A Rheodyne injector $7725 \mathrm{i}$ fitted with a $20 \mu \mathrm{L}$ loop was used and data were recorded and evaluated by use of LC solutions software version 5.0.

\section{Chromatographic conditions}

Chromatographic analysis was performed on Enable C18 G column $(250 \times 4.6 \mathrm{~mm}$ i. d, $5 \mu)$. The mobile phase consisted of sodium acetate buffer $(\mathrm{pH} 4.0)$ and acetonitrile $(30: 70, \% \mathrm{v} / \mathrm{v})$. The flow rate was $0.6 \mathrm{ml} / \mathrm{min}$, injection volume was $20 \mu \mathrm{l}$ and detection was carried out at $238 \mathrm{~nm}$ using a UV detector.

\section{Preparations of amlodipine besylate and irbesartan stock solution}

Stock solution of amlodipine besylate $(1000 \mu \mathrm{g} / \mathrm{ml})$ and irbesartan $(1000 \mu \mathrm{g} / \mathrm{ml})$ was prepared separately by transferring accurately weighed $50 \mathrm{mg}$ of amlodipine besylate and $50 \mathrm{mg}$ of Irbesartan into a $50 \mathrm{ml}$ volumetric flask and to it added a $20 \mathrm{ml}$ methanol. The mixture was sonicated for $5 \mathrm{~min}$ to dissolve the drug and the solution was diluted up to the mark with methanol. Standard solution amlodipine besylate $(100 \mu \mathrm{g} / \mathrm{ml})$ and irbesartan $(100 \mu \mathrm{g} / \mathrm{ml})$ were prepared by diluting $10 \mathrm{ml}$ of standard stock solution to $100 \mathrm{ml}$ in a volumetric flask with mobile phase. To prepare a binary mixture of irbesartan and amlodipine besylate appropriate volume of standard solution was transferred into a $100 \mathrm{ml}$ volumetric flask and diluted with mobile phase to get a solution containing $100 \mu \mathrm{g} / \mathrm{ml}$ of irbesartan and $10 \mu \mathrm{g} / \mathrm{ml}$ of amlodipine besylate.

\section{Analysis of amlodipine besylate and irbesartan in combined dosage form}

Accurately weighed about twenty tablets and average weight of the tablet was determined. The tablets were transferred into mortar and triturated to a fine powder form. An a liquate of the powder equivalent to $100 \mathrm{mg}$ of irbesartan and $10 \mathrm{mg}$ of amlodipine besylate was transferred into a $100 \mathrm{ml}$ volumetric flask. To it $20 \mathrm{ml}$ HPLC grade methanol was added and sonicated for 5 min to dissolve the drugs. The content of the flask was kept for 10 min at laboratory temperature and diluted up to mark with HPLC grade methanol this gives a concentration of irbesartan $1000 \mu \mathrm{g} / \mathrm{ml}$ and amlodipine besylate $100 \mu \mathrm{g} / \mathrm{ml}$. The above solution was filtered through $0.2 \mu$ membrane filter. The $6 \mathrm{ml}$ of the filtrate was transferred into a 100 $\mathrm{ml}$ volumetric flask and diluted with mobile phase to get a concentration of $60 \mu \mathrm{g} / \mathrm{ml}$ and $6 \mu \mathrm{g} / \mathrm{ml}$ for irbesartan and amlodipine besylate respectively.

\section{Method validation}

The method was validated for accuracy, precision, linearity, specificity, robustness, limit of detection, limit of quantitation and system suitability.

\section{Linearity}

Linearity was performed by preparing standard solutions of irbesartan and amlodipine besylate at different concentration levels.
Irbesartan was prepared in the concentration range of $10-70 \mu \mathrm{g} / \mathrm{ml}$ and $4-32 \mu \mathrm{g} / \mathrm{ml}$ for amlodipine besylate. Twenty microlitres of each concentration from both drug solutions were injected in duplicate into the HPLC system. The response was carried out at $238 \mathrm{~nm}$ and the corresponding chromatograms were recorded from these mean peak areas were calculated. The calibration curve was plotted by taking concentration on $\mathrm{x}$-axis and peak areas on $\mathrm{y}$-axis for both the drugs.

\section{Accuracy}

The accuracy of the method evaluated by standard addition method in which a known amount of standard drug was added to the fixed amount of pre-analyzed tablet solution. Percent recovery of irbesartan and amlodipine besylate was calculated at three concentration levels of $80 \%, 100 \%$ and $120 \%$. The solutions were analyzed in triplicate at each level. The percent recovery and \% relative standard deviation (RSD) at each level was calculated.

\section{Precision}

Precision of the method was evaluated as system precision and method precision.

To study the system precision, six replicate standard solutions of irbesartan and amlodipine besylate were analysed. The percent relative standard deviation (\% RSD) was calculated for both irbesartan and amlodipine besylate.

Method precision of the analytical method was carried out on six preparations from the tablet formulation and percentage amount of irbesartan and amlodipine besylate in the tablet formulation was calculated. The intraday and interday precision study were conducted for both irbesartan and amlodipine besylate. The mean \% assay value, standard deviation and percent relative standard deviation was calculated [50].

\section{Limit of detection (LOD) and limit of quantitatation (LOQ)}

LOD was measured by serially diluting the standard solutions of irbesartan and amlodipine besylate and determining the concentration was the response of sample peaks are three times the noise peak. LOQ was measured by serially diluting the standard solutions of irbesartan and amlodipine besylate and determining the concentration was the response of sample peaks are ten times the noise peak [51].

\section{Robustness}

Robustness of the method was determined by making slight changes in the composition of organic phase $\pm 5 \%, \mathrm{p}^{\mathrm{H}} \mathrm{by} \pm 0.2$, flow rate $\mathrm{by} \pm 0.1$ $\mathrm{ml} / \mathrm{min}$ and detection wavelength by $\pm 2 \mathrm{~nm}$.

\section{Specificity}

The specificity of the proposed method was determined against blank and placebo applications. Here mobile phase was used as blank and excipients like starch, lactose, magnesium stearate were used as placebo [52]

\section{Forced degradation studies}

Different stress conditions were used for the forced degradation studies of the formulation. These were also used to evaluate the specificity of the method. All the samples were diluted with mobile phase and filtered through $0.2 \mu$ membrane filter.

\section{Acidic conditions}

Weighed accurately about twenty tablets and triturated it to a fine powder form. An a liquate of the powder equivalent to $100 \mathrm{mg}$ of irbesartan and $10 \mathrm{mg}$ of amlodipine besylate was transferred into a $100 \mathrm{ml}$ volumetric flask. To this added a $50 \mathrm{ml}$ of diluent and sonicated for $10 \mathrm{~min}$ to dissolve the drug completely. Then $10 \mathrm{ml}$ of $5 \mathrm{~N} \mathrm{HCl}$ was added to it, refluxed for $6 \mathrm{hr}$ at $60^{\circ} \mathrm{C}$, cooled to room temperature, neutralized with $5 \mathrm{~N} \mathrm{NaOH}$ and diluted up to the mark with the diluent. The above sample solution was filtered through 0.2 $\mu$ nylon membrane filter. Pipetted $6 \mathrm{ml}$ of the above filtered sample solution into a $100 \mathrm{ml}$ volumetric flask and volume made up to the mark with diluent. 


\section{Alkaline conditions}

Weighed accurately about twenty tablets and triturated it to a fine powder form. An a liquate of the powder equivalent to $100 \mathrm{mg}$ of irbesartan and $10 \mathrm{mg}$ of amlodipine besylate was transferred into a $100 \mathrm{ml}$ volumetric flask. To this added a $50 \mathrm{ml}$ of diluent and sonicated for $10 \mathrm{~min}$ to dissolve the drug completely. Then $10 \mathrm{ml}$ of $5 \mathrm{~N} \mathrm{NaOH}$ was added to it, refluxed for $6 \mathrm{hr}$ at $60^{\circ} \mathrm{C}$, cooled to room temperature, neutralized with $5 \mathrm{~N} \mathrm{HCl}$ and diluted up to the mark with the diluent. The above sample solution was filtered through $0.2 \mu$ nylon membrane filter. Pipetted $6 \mathrm{ml}$ of the above-filtered sample solution into a $100 \mathrm{ml}$ volumetric flask and volume made up to the mark with diluent.

\section{Oxidative degradation}

Weighed accurately about twenty tablets and triturated it to a fine powder form. An a liquate of the powder equivalent to $100 \mathrm{mg}$ of irbesartan and $10 \mathrm{mg}$ of amlodipine besylate was transferred into a $100 \mathrm{ml}$ volumetric flask. To this added a $50 \mathrm{ml}$ of diluent and sonicated for $10 \mathrm{~min}$ to dissolve the drug completely. Then $5 \mathrm{ml}$ of $30 \%$ hydrogen peroxide was added, refluxed for $2 \mathrm{hr}$ at $60^{\circ} \mathrm{C}$, then cooled to room temperature and diluted up to the mark with diluents. The above sample solution was filtered through $0.2 \mu$ nylon membrane filter. Pipetted $6 \mathrm{ml}$ of the above-filtered sample solution into a $100 \mathrm{ml}$ volumetric flask and volume made up to the mark with diluent.

\section{Thermal degradation}

Weighed accurately about twenty tablets and triturated it to a fine powder form. The powder sample was subjected to thermal stress at $105^{\circ} \mathrm{C}$ for about $2 \mathrm{~d}$. An a liquate of the powder equivalent to 100 $\mathrm{mg}$ of irbesartan and $10 \mathrm{mg}$ of amlodipine besylate was transferred into a $100 \mathrm{ml}$ volumetric flask. To this added a $50 \mathrm{ml}$ of diluent and sonicated for $10 \mathrm{~min}$ to dissolve the drug completely the diluted up to mark with diluents. The above sample solution was filtered through $0.2 \mu$ nylon membrane filter. Pipetted $6 \mathrm{ml}$ of the abovefiltered sample solution into a $100 \mathrm{ml}$ volumetric flask and volume made up to the mark with diluent.

\section{Photolytic degradation}

Weighed accurately about twenty tablets and triturated it to a fine powder form. The powder sample was subjected to UV light in a photo stability chamber for about $10 \mathrm{~d}$. An a liquate of the powder equivalent to $100 \mathrm{mg}$ of irbesartan and $10 \mathrm{mg}$ of amlodipine besylate was transferred into a $100 \mathrm{ml}$ volumetric flask. To this added a $50 \mathrm{ml}$ of diluent and sonicated for $10 \mathrm{~min}$ to dissolve the drug completely the diluted up to mark with diluents. The above sample solution was filtered through $0.2 \mu$ nylon membrane filter. Pipetted $6 \mathrm{ml}$ of the above-filtered sample solution into a $100 \mathrm{ml}$ volumetric flask and volume made up to the mark with diluent.

\section{RESULTS}

\section{Optimization of chromatographic conditions}

In the present work, an analytical method based on RP-HPLC using UV detection was developed and validated for simultaneous estimation of irbesartan and amlodipine besylate in the pharmaceutical formulation. The selection of analytical conditions was based on the chemical nature of irbesartan and amlodipine besylate. A systematic study of various factors was undertaken by varying one parameter at a time and keeping all other conditions constant for development of an analytical method. Both irbesartan and amlodipine besylate were soluble in polar solvents, therefore, RP-HPLC was chosen. The selection of the stationary phase has been done on the basis of back pressure, resolution, peak shape, theoretical plates and day to day reproducibility in retention time resolution between irbesartan and amlodipine besylate peaks. After evaluating all these factors Enable C18 G column $(250$ x $4.6 \mathrm{~mm}$ i. d $5 \mu$ ) was chosen for the analysis. The selection of buffer was based on the chemical structure of selected drug molecules. For optimization of mobile phase, preliminary trials were conducted under isocratic conditions using mobile phases composed of the mixture of solvents like water, methanol and actonitrile with or without different buffers in different combinations. A mixture of sodium acetate buffer $\mathrm{p}^{\mathrm{H}} 4.0$ and acetonitrile in the ratio of $30: 70 \mathrm{v} / \mathrm{v}$ was found to be most suitable of all the combinations since the chromatographic peaks obtained were having good system suitability parameters. The Flow rate of the mobile phase was optimized based on the resolution between chromatographic peaks and minimal solvent consumption. The flow rate of mobile phase was changed from $0.5-2 \mathrm{ml} / \mathrm{min}$. It was found from trials that $0.6 \mathrm{ml} / \mathrm{min}$ flow rate was ideal for successful elution of both drugs. For a selection of analytical wavelength standard solutions of both drugs were scanned in the wavelength range of $200-350 \mathrm{~nm}$. A detection wavelength of $238 \mathrm{~nm}$ was selected. The chromatogram of the sample was shown in fig. 3 .

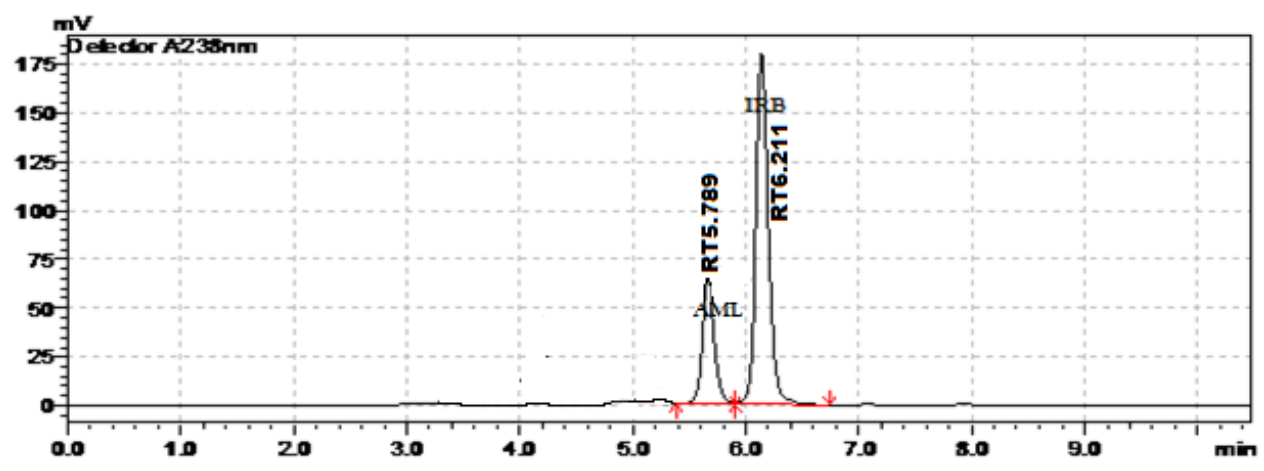

Fig. 3: Chromatogram of amlodipine besylate and Irbesartan

Table 1: Linearity data for amlodipine besylate

\begin{tabular}{|c|c|c|}
\hline S. No. & Concentration of amlodipine besylate $(\mu \mathrm{g} / \mathrm{ml})$ & Peak area \\
\hline 1 & 4 & 191223 \\
\hline 2 & 8 & 382459 \\
\hline 3 & 12 & 573701 \\
\hline 4 & 16 & 764877 \\
\hline 5 & 20 & 956106 \\
\hline 6 & 24 & 1147398 \\
\hline 7 & 28 & 1338561 \\
\hline 8 & 32 & 1529772 \\
\hline \multicolumn{2}{|c|}{ Slope } & 47806 \\
\hline \multicolumn{2}{|c|}{ Intercept } & 11.786 \\
\hline \multicolumn{2}{|c|}{ Correlation Coefficient } & 0.9999 \\
\hline
\end{tabular}




\section{Method validation}

Linearity was studied by preparing standard solutions at different concentration levels. The linearity ranges for amlodipine besylate and irbesartan were found to be $4-32 \mu \mathrm{g} / \mathrm{ml}$ and $10-70 \mu \mathrm{g} / \mathrm{ml}$ respectively. The linear regression equation for amlodipine besylate was found to be $47806 x+11.786$ with correlation coefficient 0.9999 . The linear regression equation for irbesartan was found to be 62825 $\mathrm{x}-16.143$ with correlation coefficient 0.9998 . The calibration table for amlodipine besylate and irbesartan was shown in table 1 and table 2 respectively. The calibration curve of amlodipine besylate and irbesartan were shown in fig. 4 and fig. 5 respectively.

\section{Accuracy}

The percent recovery of irbesartan and amlodipine besylate was found to be 100.43-101 \% and 100.07-100.52\%. This indicates the accuracy of the method. The results are shown in table 3 and 4.

Table 2: Linearity data for Irbesartan

\begin{tabular}{llc}
\hline S. No. & Concentration of Irbesartan $(\boldsymbol{\mu g} / \mathbf{m l})$ & Peak area \\
\hline 1 & 10 & 628247 \\
2 & 20 & 1256484 \\
3 & 30 & 1884758 \\
4 & 40 & 2512971 \\
5 & 50 & 3141220 \\
6 & 60 & 3769498 \\
7 & & 4397771 \\
Slope & & 62825 \\
Intercept & & -16.143 \\
Correlation Coefficient & 0.9998 \\
\hline
\end{tabular}

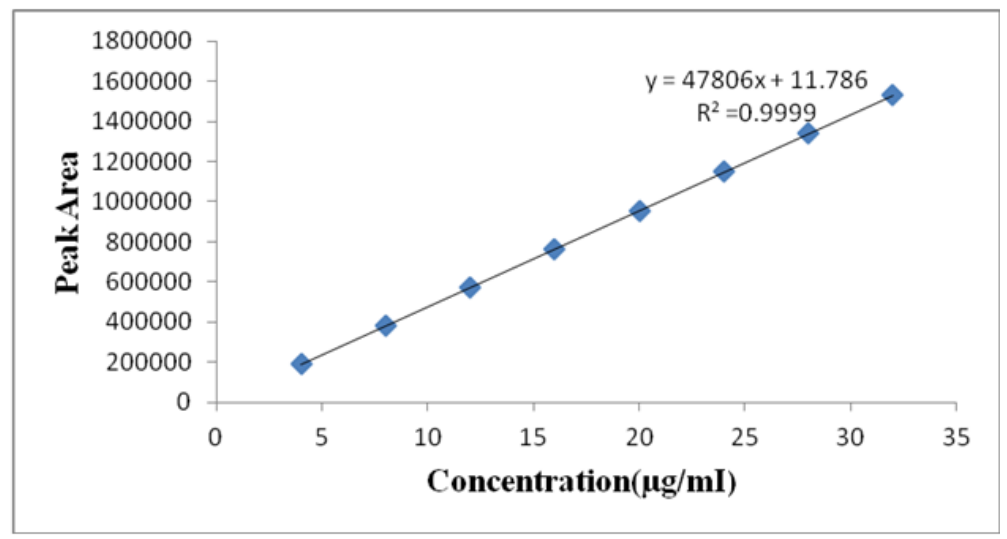

Fig. 4: Linearity plot of amlodipine besylate

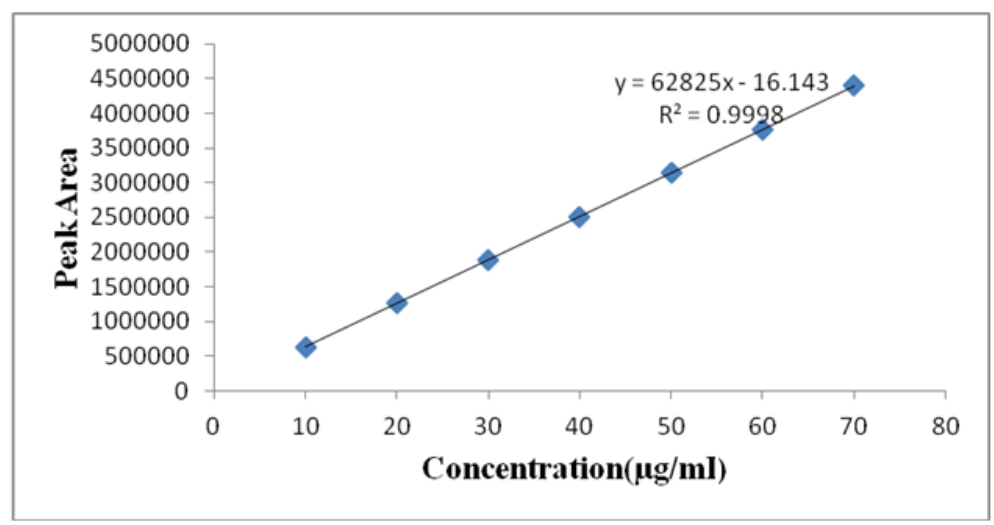

Fig. 5: Linearity plot of irbesartan

Table 3: Accuracy results of Irbesartan $(n=3)$

\begin{tabular}{|c|c|c|c|c|}
\hline Drug Name & Level of addition (\%) & Amount taken $(\mu \mathrm{g} / \mathrm{ml})$ & Amount found $(\mu \mathrm{g} / \mathrm{ml}(\mathrm{mean} \pm \mathrm{SD})$ & $\%$ recovery (mean \pm SD) \\
\hline \multirow{3}{*}{ Irbesartan } & 80 & 48 & 48.41 & $100.88 \pm 0.80$ \\
\hline & 100 & 60 & 60.25 & $100.43 \pm 0.31$ \\
\hline & 120 & 72 & 72.71 & $101 \pm 0.75$ \\
\hline
\end{tabular}

$\mathrm{n}$ is number of determinations, $\mathrm{SD}$ is standard deviation 
Table 4: Accuracy results of amlodipine besylate $(n=3)$

\begin{tabular}{lllll}
\hline Drug Name & Level of addition (\%) & Amount taken $(\boldsymbol{\mu g} / \mathbf{m l})$ & Amount found $(\boldsymbol{\mu g} / \mathbf{m l}(\mathbf{m e a n} \pm \mathbf{S D})$ & $\mathbf{\%} \mathbf{r e c o v e r y}(\mathbf{m e a n} \pm \mathbf{S D})$ \\
\hline & 80 & 4.8 & 4.80 & $100.07 \pm 0.41$ \\
Amlodipine Besylate & 100 & 6.0 & 6.02 & $100.52 \pm 0.21$ \\
& 120 & 7.2 & 7.22 & $100.45 \pm 0.51$ \\
\hline
\end{tabular}

$\mathrm{n}$ is number of determinations, SD is standard deviation

Table 5: System precision results for irbesartan and amlodipine besylate

\begin{tabular}{lll}
\hline Injection No. & Peak area of irbesartan & Peak area of amlodipine besylate \\
\hline 1 & 3769498 & 286847 \\
2 & 3713456 & 289114 \\
3 & 3728862 & 279912 \\
4 & 3719841 & 285318 \\
5 & 3758423 & 284877 \\
6 & 3788912 & 286006 \\
Mean & 3746499 & 285345.7 \\
SD & 30277.22 & 3054.03 \\
\%RSD & 0.80 & 1.07 \\
\hline
\end{tabular}

Table 6: Method precision results for Irbesartan and amlodipine besylate $(n=6)$

\begin{tabular}{llll}
\hline \multirow{2}{*}{ Set } & Irbesartan & Amlodipine besylate \\
\cline { 2 - 4 } & Intraday (mean \pm SD) & Interday (mean \pm SD) & Intraday (mean \pm SD) \\
\hline \% Assay & $100.69 \pm 0.4385$ & $101.04 \pm 0.3033$ & $99.76 \pm 0.435$ \\
\% RD & 0.435 & 0.30 & 0.436 \\
\hline
\end{tabular}

$\mathrm{n}$ is number of determinations, SD is standard deviation, RSD is relative standard deviation

\section{Precision}

\section{System precision}

The \% relative standard deviation (RSD) for irbesartan was found to be 0.80 and for amlodipine besylate was found to be 1.07 which are within the acceptance criteria of not more than 2.0 indicates the precision of the method. The precision data was shown in table 5 .

\section{Method precision}

The \% relative standard deviation (RSD) for Intraday and Interday precision assay results of six preparations for irbesartan were found to be 0.435 and 0.30 respectively which are within the acceptance criteria of not more than 2.0 indicates the precision of the method. The \% relative standard deviation (RSD) for Intraday and Interday precision assay results of six preparations for amlodipine besylate were found to be 0.436 and 0.699 S respectively which are within the acceptance criteria of not more than 2.0 indicates the precision of the method. The precision data was shown in table 6 .

\section{Limit of detection and limit of quantitation}

LOD and LOQ were calculated from the standard deviation of response and slope of the calibration curve of irbesartan and amlodipine besylate. The LOD and LOQ were found to be 0.0327 $\mu \mathrm{g} / \mathrm{ml}$ and $0.1097 \mu \mathrm{g} / \mathrm{ml}$ for amlodipine besylate and the LOD and LOQ for irbesartan were $0.0514 \mu \mathrm{g} / \mathrm{ml}$ and $0.1559 \mu \mathrm{g} / \mathrm{ml}$, which shown that the developed method was sensitive and it can detect and quantify at the lower concentration.

\section{Robustness}

To evaluate the robustness of the developed method, small deliberate variations in optimized method parameters were made. The effect of the change in flow rate, change in $\mathrm{pH}$, change in the composition of mobile phase and detection wavelength on retention time, tailing factor and theoretical plates were studied. The method was found to be unaffected by small changes in flow rate, change in $\mathrm{pH}$, change in the composition of mobile phase and detection wavelength as shown in table 7 and table 8 .

\section{Specificity}

Specificity is the ability to unequivocally assess the analyte in the presence of components that may be expected to be present. Typically, these might include impurities, degradants or matrix. Specificity of an analytical method is its ability to accurately and specifically measure the analyte of interest without interference from blank or placebo. The peak purities of amlodipine besylate and irbesartan were assessed by comparing the retention times of standard amlodipine besylate and irbesartan and the sample, and good correlation was obtained between the retention time of the standard and sample. Placebo and blank were injected and there were no peaks. There is no interference of degradation peaks on drug peaks hence, the method is specific. The specificity results are shown in table 9.

Table 7: Robustness results for amlodipine besylate $(n=3)$

\begin{tabular}{|c|c|c|c|}
\hline \multirow[t]{2}{*}{ Conditions } & \multirow[t]{2}{*}{ \% Assay (mean \pm SD) } & \multicolumn{2}{|l|}{ System suitability parameters } \\
\hline & & Theoretical plates (mean \pm SD) & Tailing factor (mean \pm SD) \\
\hline Flow Rate $0.5 \mathrm{ml} / \mathrm{min}$ & $99.23 \pm 0.33$ & $5309 \pm 0.37$ & $1.21 \pm 0.39$ \\
\hline Flow Rate $0.7 \mathrm{ml} / \mathrm{min}$ & $99.14 \pm 0.21$ & $5105 \pm 0.67$ & $1.49 \pm 0.31$ \\
\hline Mobile Phase-Buffer(35):Acetonitrile(65) & $100.83 \pm 0.78$ & $4983 \pm 0.42$ & $1.42 \pm 0.89$ \\
\hline Mobile Phase-Buffer(25):Acetonitrile(75) & $99.12 \pm 0.96$ & $4862 \pm 0.28$ & $1.39 \pm 0.88$ \\
\hline Mobile Phase $\mathrm{p}^{\mathrm{H}} 3.8$ & $101.32 \pm 0.66$ & $4821 \pm 0.91$ & $1.61 \pm 0.60$ \\
\hline Mobile Phase $\mathrm{p}^{\mathrm{H}} 4.2$ & $99.55 \pm 0.54$ & $5129 \pm 0.56$ & $1.59 \pm 0.95$ \\
\hline Wavelength $236 \mathrm{~nm}$ & $99.68 \pm 0.85$ & $5157 \pm 0.44$ & $1.53 \pm 0.87$ \\
\hline Wavelength $240 \mathrm{~nm}$ & $99.87 \pm 0.21$ & $5004 \pm 0.36$ & $1.52 \pm 0.92$ \\
\hline
\end{tabular}

$\mathrm{n}$ is number of determinations, $\mathrm{SD}$ is the standard deviation 
Table 8: Robustness results for Irbesartan $(n=3)$

\begin{tabular}{llll}
\hline Conditions & \% Assay (mean \pm SD) & System suitability parameters \\
\cline { 3 - 4 } & & Theoretical plates (mean \pm SD) & Tailing factor(mean \pm SD) \\
\hline Flow Rate $0.5 \mathrm{ml} / \mathrm{min}$ & $99.82 \pm 0.48$ & $3340 \pm 0.67$ & $1.33 \pm 0.87$ \\
Flow Rate $0.7 \mathrm{ml} / \mathrm{min}$ & $99.74 \pm 0.66$ & $3030 \pm 0.39$ & $1.54 \pm 0.91$ \\
MobilePhase-Buffer(35):Acetonitrile(65) & $100.25 \pm 0.75$ & $3289 \pm 0.74$ & $1.23 \pm 0.48$ \\
Mobile Phase-Buffer(25):Acetonitrile (75) & $100.63 \pm 0.58$ & $3373 \pm 0.84$ & $1.28 \pm 0.87$ \\
Mobile Phase $\mathrm{p}^{\mathrm{H}} 3.8$ & $99.66 \pm 0.67$ & $3116 \pm 0.61$ & $1.53 \pm 0.37$ \\
Mobile Phase $\mathrm{p}^{\mathrm{H}} 4.2$ & $100.79 \pm 0.91$ & $3193 \pm 0.59$ & $1.34 \pm 0.54$ \\
Wavelength $236 \mathrm{~nm}$ & $99.83 \pm 0.49$ & $3288 \pm 0.78$ & $1.37 \pm 0.82$ \\
Wavelength $240 \mathrm{~nm}$ & $99.78 \pm 0.78$ & $3462 \pm 0.42$ & $1.35 \pm 0.69$ \\
\hline
\end{tabular}

$\mathrm{n}$ is number of determinations, SD is standard deviation

Table 9: Specificity results of the method $(n=6)$

\begin{tabular}{ll}
\hline Name of solution & Retention time (min) (mean \pm SD) \\
\hline Blank & No peaks \\
Placebo & No Peaks \\
Irbesartan & $6.321 \pm 0.78$ \\
Amlodipine Besylate & $5.579 \pm 0.91$ \\
\hline
\end{tabular}

$\mathrm{n}$ is number of determinations, $\mathrm{SD}$ is standard deviation

Table 10: Analysis of amlodipine besylate and Irbesartan in the commercial formulation

\begin{tabular}{lllllll}
\hline Formulation & Labelled claim(mg) & & Amount found*(mg) & & \%Recovery* \pm \%RD \\
\cline { 2 - 7 } & Amlodipine besylate & Irbesartan & Amlodipine besylate & Irbesartan & Amlodipine besylate & Irbesartan \\
\hline AMIX R TABLETS & 10 & 100 & 9.96 & 100.06 & $99.96 \pm 0.42$ & $100.6 \pm 0.56$ \\
\hline
\end{tabular}

*Average of three determinations

\section{Analysis of commercial formulation}

The proposed method was applied for the determination of amlodipine besylate and irbesartan in marketed formulations available (AMIX R TABLETS). The \% recovery was found to be $99.96 \pm 0.42$ and $100.6 \pm 0.56$ for amlodipine besylate and irbesartan respectively table 10 .

\section{Results of forced degradation studies}

Under acidic conditions amlodipine, besylate degraded to $3.44 \%$ and irbesartan degraded to $10.66 \%$. In these stress conditions, the retention time of degradation peaks appears at $4.2132 \mathrm{~min}$ and $5.182 \mathrm{~min}$. In basic conditions amlodipine, besylate degraded to $30.44 \%$ and irbesartan degraded to $18.46 \%$. Under these conditions, five degradant peaks appear at retention times of 3.812 min, $4.252 \mathrm{~min}, 4.754 \mathrm{~min}, 5.255 \mathrm{~min}$ and $9.511 \mathrm{~min}$. In oxidative conditions amlodipine, besylate degraded to $30.36 \%$ and irbesartan to $30.42 \%$. Although both drugs degraded to a significant extent but only two minor peaks are detected at retention times of $3.345 \mathrm{~min}$ and $4.366 \mathrm{~min}$. In thermal conditions amlodipine, besylate degraded to $0.43 \%$ and irbesartan degraded to $5.06 \%$ but there is no appearance of degradant peaks on the chromatogram. In photolytic conditions amlodipine, besylate degraded to $28.72 \%$ and irbesartan degraded to $15.66 \%$ here also both the drugs degraded to a significant extent but only two minor peaks are detected at retention times of $3.332 \mathrm{~min}$ and $4.414 \mathrm{~min}$. Amlodipine besylate shown stability towards acidic and thermal in it degraded to a lesser extent whereas in basic, oxidative and photolytic it shown less stability in which it degraded to more extent. Irbesartan shown stability towards thermal conditions whereas in remaining conditions it degrades to more extent especially in Oxidative conditions.

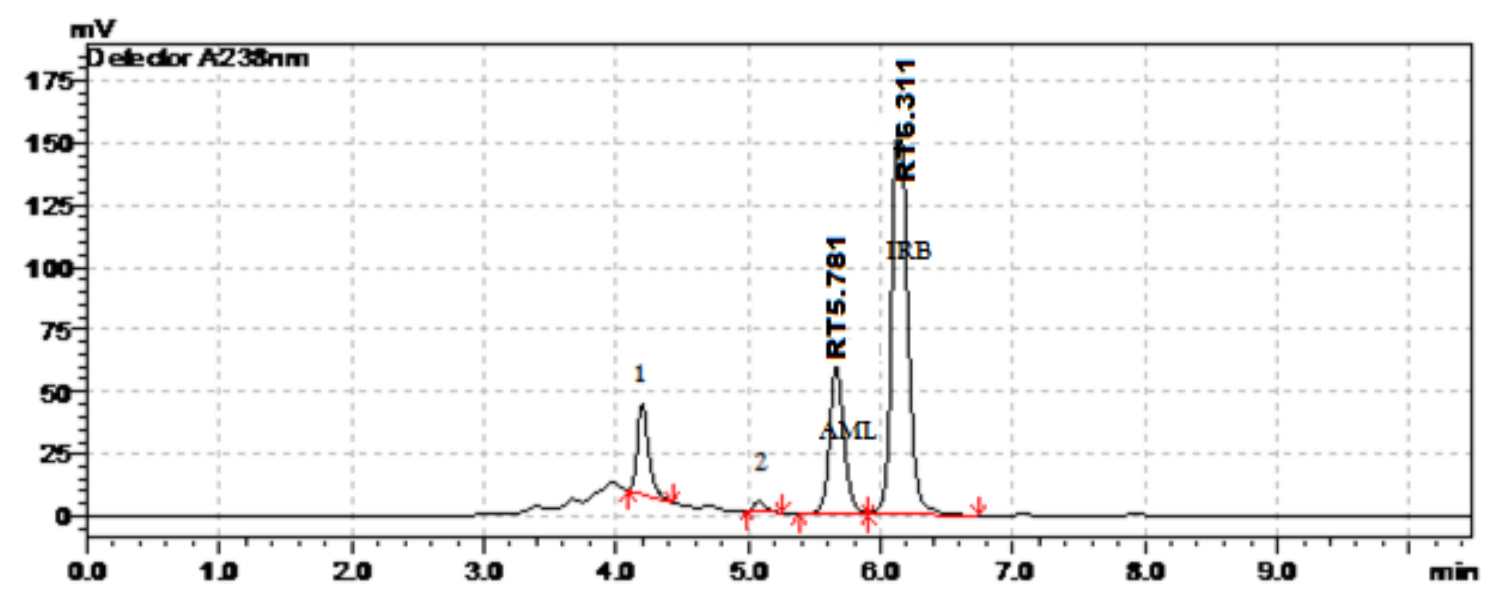

Fig. 6: Acid degradation chromatogram 


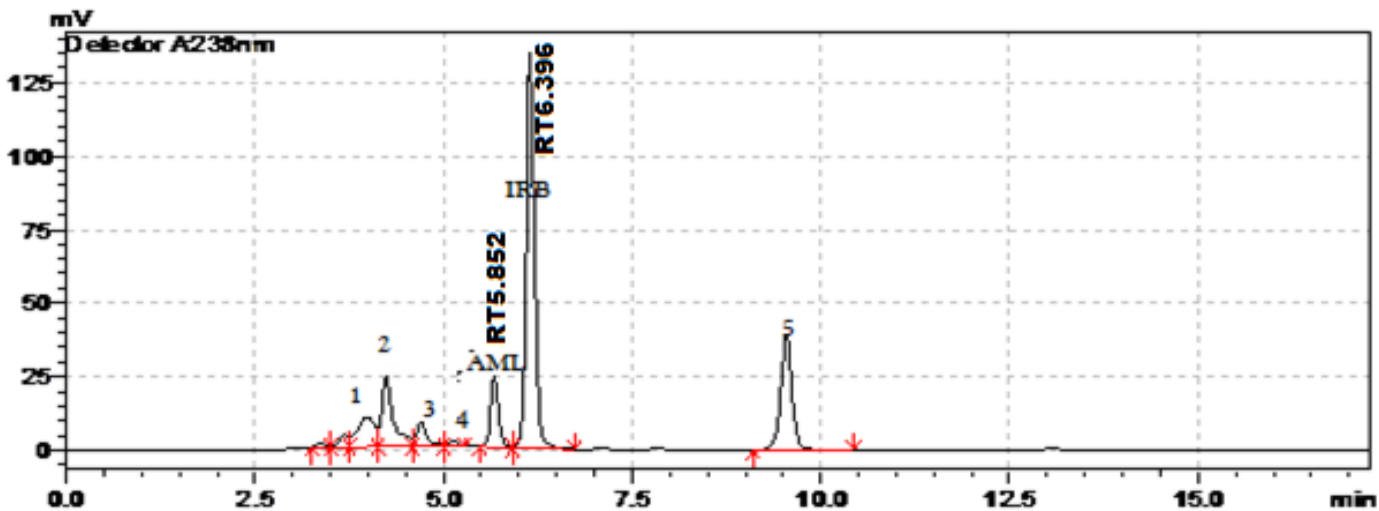

Fig. 7: Base degradation chromatogram

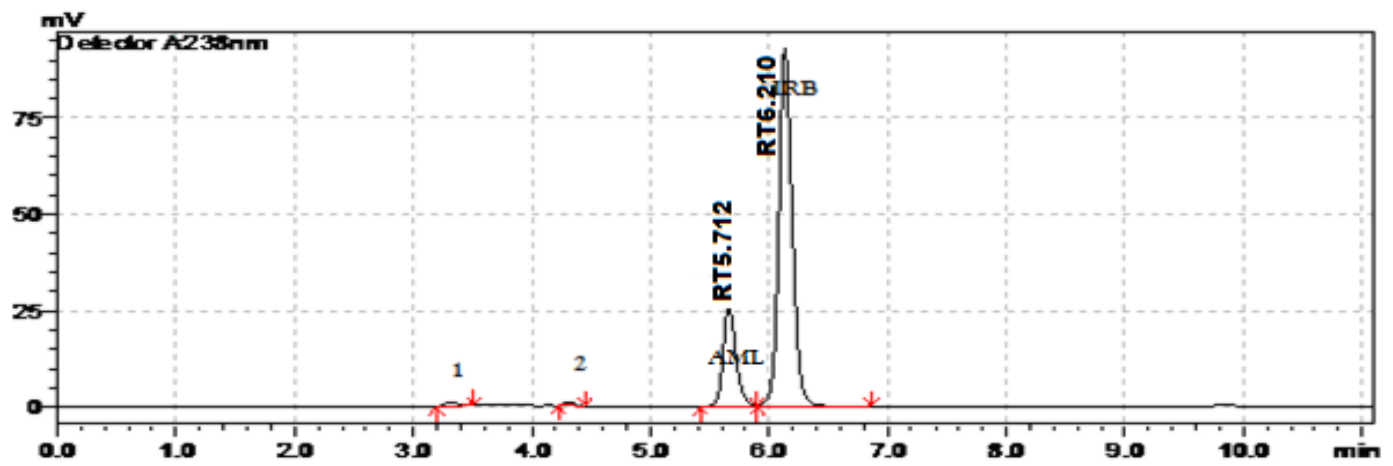

Fig. 8: Oxidative degradation chromatogram

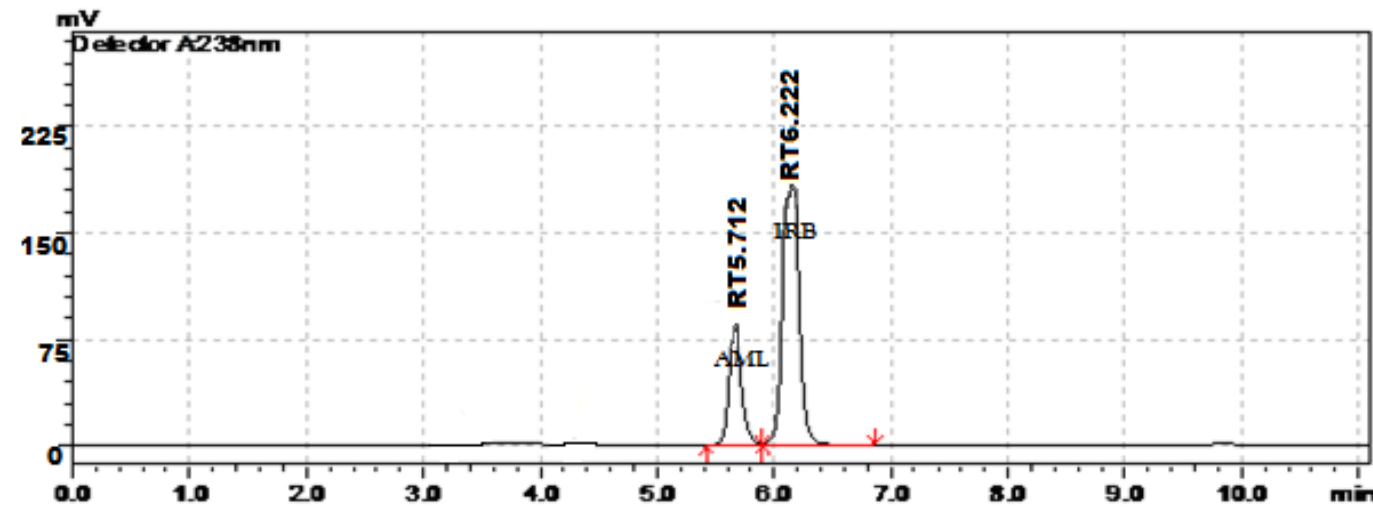

Fig. 9: Thermal degradation chromatogram

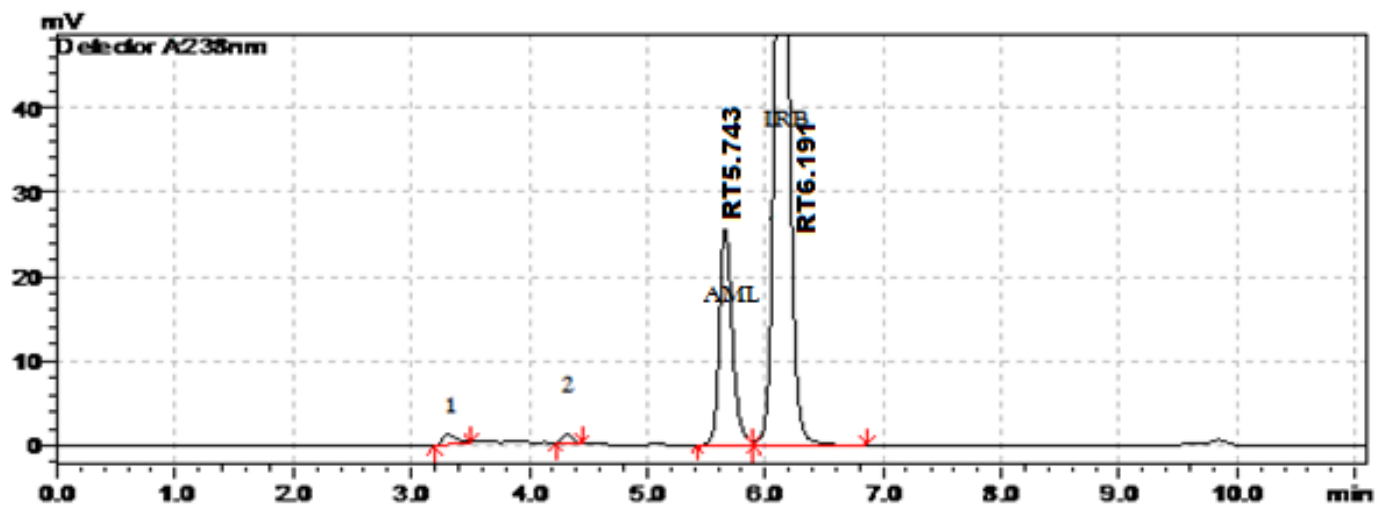

Fig. 10: Photolytic degradation chromatogram 
Table 11: Forced degradation studies of Irbesartan and amlodipine besylate $(n=3)$

\begin{tabular}{|c|c|c|c|c|c|c|}
\hline Stress conditions & Duration & $\begin{array}{l}\text { \%Drug } \\
\text { recovered } \\
\text { (mean } \pm \text { SD) }\end{array}$ & $\begin{array}{l}\text { \% Drug decomposed } \\
\text { (mean } \pm \text { SD) }\end{array}$ & $\begin{array}{l}\text { Retention time (min) } \\
(\text { mean } \pm \text { SD) }\end{array}$ & $\begin{array}{l}\text { Theoretical } \\
\text { plates } \\
\text { (mean } \pm \text { SD) }\end{array}$ & $\begin{array}{l}\text { Tailing } \\
\text { factor } \\
\text { (mean } \pm \text { SD) }\end{array}$ \\
\hline \multicolumn{7}{|l|}{ Irbesartan } \\
\hline Control Sample & --- & $99.96 \pm 1.21$ & --- & $6.231 \pm 1.22$ & $3440 \pm 1.89$ & $1.43 \pm 0.56$ \\
\hline Acid Degradation & $6 \mathrm{~h}$ & $89.30 \pm 1.09$ & $10.66 \pm 1.09$ & $6.311 \pm 1.65$ & $3598 \pm 1.73$ & $1.52 \pm 0.89$ \\
\hline Alkaline degradation & $6 \mathrm{~h}$ & $81.5 \pm 0.98$ & $18.46 \pm 0.98$ & $6.396 \pm 1.89$ & $3462 \pm 1.56$ & $1.39 \pm 0.45$ \\
\hline Oxidative Degradation & $2 \mathrm{~h}$ & $69.54 \pm 1.65$ & $30.42 \pm 1.65$ & $6.210 \pm 0.36$ & $3786 \pm 0.99$ & $1.32 \pm 0.29$ \\
\hline Thermal Degradation & $2 \mathrm{~d}$ & $94.9 \pm 1.53$ & $5.06 \pm 1.53$ & $6.222 \pm 0.87$ & $3580 \pm 1.09$ & $1.31 \pm 0.84$ \\
\hline $\begin{array}{c}\text { Photolytic Degradation } \\
\text { Amlodipine Besylate }\end{array}$ & $10 \mathrm{~d}$ & $84.3 \pm 0.78$ & $15.66 \pm 0.78$ & $6.191 \pm 0.89$ & $3582 \pm 1.54$ & $1.56 \pm 0.99$ \\
\hline Control Sample & ---- & $100.06 \pm 1.56$ & ----- & $5.789 \pm 0.66$ & $5225 \pm 0.92$ & $1.24 \pm 0.74$ \\
\hline Acid Degradation & $6 \mathrm{~h}$ & $96.62 \pm 1.36$ & $3.44 \pm 1.36$ & $5.781 \pm 1.23$ & $5853 \pm 0.39$ & $1.19 \pm 0.52$ \\
\hline Alkaline Degradation & $6 \mathrm{~h}$ & $69.62 \pm 1.57$ & $30.44 \pm 1.57$ & $5.852 \pm 0.78$ & $5674 \pm 0.66$ & $1.26 \pm 0.33$ \\
\hline Oxidative Degradation & $2 \mathrm{~h}$ & $69.7 \pm 1.62$ & $30.36 \pm 1.62$ & $5.712 \pm 0.44$ & $5281 \pm 0.98$ & $1.21 \pm 0.92$ \\
\hline Thermal Degradation & $2 \mathrm{~d}$ & $99.63 \pm 1.78$ & $0.43 \pm 1.78$ & $5.712 \pm 0.60$ & $5736 \pm 0.79$ & $1.21 \pm 0.78$ \\
\hline Photolytic Degradation & $10 \mathrm{~d}$ & $71.34 \pm 1.41$ & $28.72 \pm 1.41$ & $5.743 \pm 0.61$ & $5452 \pm 1.67$ & $1.32 \pm 0.68$ \\
\hline
\end{tabular}

$\mathrm{n}$ is number of determinations, SD is standard deviation

\section{DISCUSSION}

The present RP-HPLC method is a simple, precise, specific, accurate, linear and robust for analyzing irbesartan and amlodipine besylate in the sample mixture. The results obtained from the above set of observations prove that the method is useful in qualitative and quantitative analysis of irbesartan and amlodipine besylate in dosage forms. There are some RP-HPLC methods reported for the estimation of irbesartan and amlodipine besylate in dosage forms and biological fluids but the methods have the drawbacks as not of stability indicating $[46,47]$, having long retention time and low linearity range [48]. In the present method, a mixture of sodium acetate buffer $\mathrm{p}^{\mathrm{H}} 4.0$ and acetonitrile in the ratio of $30: 70 \mathrm{v} / \mathrm{v}$ as mobile phase found to be most suitable of analysis of irbesartan and amlodipine besylate, since the chromatographic peaks obtained were having good system suitability parameters. The method was validated according to ICH guidelines and results were in compliance of ICH guidelines. The linearity of the method had a good correlation with concentration and peak area. The correlation coefficient of irbesartan and amlodipine besylate was found to be 0.999 , which indicates good linear relationship over concentration range $10-70 \mu \mathrm{g} / \mathrm{ml}$ and $8-32 \mu \mathrm{g} / \mathrm{ml}$ for irbesartan and amlodipine besylate respectively. The \% RSD values in intra-day and inter-day precision study were found to be less than 2 for irbesartan and amlodipine besylate, which indicate the method was precise. The amount of drug recovery was $99.96 \%$ for amlodipine besylate and $100.6 \%$ for irbesartan. Hence, the present developed method was said to be suitable for the analysis of drugs in their pharmaceutical dosage form. The developed method is stability indicating in nature, use of economical mobile phase and short chromatographic time.

\section{CONCLUSION}

The proposed method for the simultaneous estimation of amlodipine besylate and irbesartan validated as per the international conference on organization (ICH) guidelines and it is simple, specific and reliable. The data generated from the forced degradation studies enabled the evaluation of amlodipine besylate and irbesartan stability under a variety of ICH recommended conditions. These data are valuable for the safety and potency assessment of a drug product. Furthermore, this simple and rapid RP-HPLC method can also be used successfully for the determination of amlodipine besylate and irbesartan in pharmaceutical formulations without any interference from the excipient.

\section{ACKNOWLEDGMENT}

The authors are grateful to Dr. L. Rathaiah, Chairman of Lavu educational society for providing necessary facilities to carry out the above research work.

\section{AUTHORS CONTRIBUTIONS}

All the author have contributed equally.

\section{CONFLICT OF INTERESTS}

Declared none

\section{REFERENCES}

1. Naveed S, Qamar H, Jawaid W. Simple UV spectrophotometric assay of amlodipine. Am J Chem Appl 2014;1:66-9.

2. Rani KS, Swapna A, Padma A. A new spectrophotometric method for the estimation of amlodipine besylate and its stress degradation studies. Res J Pharm Biol Chem Sci 2011;2:470-2.

3. Jain N, Jain R, Jain A. Spectrophotometric method development and validation for quantitative estimation of amlodipine besylate in bulk drug and their dosage forms by using the hydrotropic agent. Eurasian J Anal Chem 2010;5:212-7.

4. Reddy K, Latha L, Sowjanya T. Development and validation of UV spectrophotometric method for estimation of amlodipine besylate in tablet dosage form. Res J Pharm Technol 2012;5:1320-3.

5. Basavaiah K, Chandrashekar U, Nagegowda P. Titrimetric and modified spectrophotometric methods for the determination of amlodipine besylate using bromate-bromide mixture and two dyes. Sci Asia 2006;32:271-8.

6. Patil VP, Devdhe SJ, Angadi SS. New eco-friendly validated spectrophotometric method for the estimation of amlodipine besylate in bulk drug using ninhydrin. Asian J Biomed Pharm Sci 2012;3:14-9.

7. Gölcü A, Yücesoy C. Colorimetric determination of amlodipine besylate in tablets. J Eng Technol 2006;9:32-6.

8. Hanaa M, Niveen A, Ashraf M. Validated spectrofluorometric methods for determination of amlodipine besylate in tablets. Spectro Chem Acta 2008;1:564-70.

9. Yooa H, Kimb TK, Leeb B. Determination of S-and R-amlodipine in rat plasma using LC-MS/MS after oral administration of Samlodipine and racemic amlodipine. Mass Spectrom Lett 2011;2:37-41.

10. Meyyanathan SN, Muralidharan S, Rajan S. A simple sample preparation with HPLC-UV method for estimation of amlodipine from plasma: application to bioequivalence study. Open Chem Biomed Methods J 2008;1:22-7.

11. Alaama M, Helal U, Mohamad HJ. Development and validation of reversed phase high performance liquid chromatographic method for determination of amlodipine. Trop J Pharm Res 2015;14:663-9.

12. Yagi S, Takashima A, Mitsugi M. Effect of combination tablets containing amlodipine $10 \mathrm{mg}$ and irbesartan $100 \mathrm{mg}$ on blood pressure and cardiovascular risk factors in patients with hypertension. Ther Clin Risk Manag 2015;11:83-8.

13. Rao SN, Kumar A, Devi RB. Estimation of irbesartan in bulk and dosage forms by new simple UV spectrophotometry using the hydrotropic technique. Pharm Anal Acta 2013;4:1-3.

14. Asati A, Shinde A, Malik S. Quantitative analysis method development and validation for irbesartan in bulk drug by ultraviolet spectroscopy. J Adv Pharm Educ 2014;4:101-4. 
15. Pradhan K, Mishra US, Pattnaik S. Method development, validation and stability study of irbesartan in bulk and pharmaceutical dosage form by UV-spectrophotometric method. Int J Pharm Biol Sci Arch 2011;2:1114-22.

16. Tulja Rani G, Gowri Sankar D, Madhavi L, Satyanarayana B. Extractive visible spectrophotometric method for determination of telmisartan and irbesartan in bulk and pharmaceutical formulations. Asian J Pharm Clin Res 2012;5:41-4.

17. Gonzalez L, Lopez JA, Alonso RM. Fast screening method for the determination of angiotensin II receptor antagonists in human plasma by high-performance liquid chromatography with fluorimetric detection. J Chromatogr A 2002;949:49-60.

18. Khanvilkar V, Shah J, Kadam I. Development and validation of HPLC assay for estimation of irbesartan in human plasma. Res J Pharm Technol 2013;6:292-5.

19. Sujana K. RP-HPLC DAD method for determination of irbesartan in bulk and tablet. Int J Pharm Res Dev 2013;3:67-73.

20. Yousheng A, Chuhong X, Huating C. Content determination of irbesartan in serum by HPLC. Chin Pharmacist; 2004.

21. Prashanthi R, Raghavi K, Sindhura M. Development and validation of a sensitive RP-HPLC-PDA method for the assay of irbesartan in pure and pharmaceutical dosage forms. Int Pharm Bio Sci 2012;3:397-407.

22. Raju RR, Babu NB. Development and validation of HPLC method for the estimation of irbesartan in the pharmaceutical dosage form. Pharmacophore 2011;2:145-9.

23. Bae SB, Kim M, Shim E. HPLC determination of irbesartan in human plasma: its application to pharmacokinetic studies. Biomed Chromatogr 2014;23:69-81.

24. Ubale MB, Thakne VD, Chaudhary VR. Simultaneous highperformance liquid chromatography determination of irbesartan and hydrochlorothiazide in the pharmaceutical dosage form. J Pharm Sci Sci Innovation 2012;1:25-8.

25. Alanaz AM, Abdelhameed AS, Khali NY. HPLC method with the monolithic column for simultaneous determination of irbesartan and hydrochlorothiazide in tablets. Acta Pharm 2014;64:187-98.

26. Vujic Z, Mulavdic N, Smajic M. Simultaneous analysis of irbesartan and hydrochlorothiazide: an improved HPLC Method. J Mol 2012;17:3461-74.

27. Hemamrutha S, Rambabu R, Vidhyadhara S. Development and validation of RP-HPLC method for simultaneous estimation of irbesartan and hydrochlorothiazide in bulk and pharmaceutical dosage forms. Int J Pharm 2013;3:360-3.

28. Raja B, Himasri P, Ramadevi B. RP-HPLC method for the simultaneous estimation of irbesartan and hydrochlorothiazide in pharmaceutical dosage form. Int Res J Pharm Appl Sci 2012;2:29-38.

29. Chabukswar AR, Jagdale SC, Kuchekar BS. Development and validation of a RP-HPLC-PDA method for simultaneous estimation of hydrochlorothiazide and irbesartan. Pharm Chem 2010;2:148-56

30. Prabhu P, Muralidhar M. Development and validation of a highperformance liquid chromatography method for simultaneous determination of irbesartan and its related impurities in pharmaceutical tablets. Int J Pharm Sci Drug Res 2014;6:145-53.

31. Hafez HM, Elshanawane AA, Abdelaziz LM. Quantitative determination of three angiotensin-II-receptor antagonists in the presence of hydrochlorothiazide by RP-HPLC in their tablet preparations. Iran J Pharm Res 2013;12:635-43.

32. Gonzalez L, Lopez JA, Alonso RM. Fast screening method for the determination of angiotensin II receptor antagonists in human plasma by high-performance liquid chromatography with fluorimetric detection. J Chromatogr A 2002;949:49-60.

33. Youssef R, Hbash A, Hassan A. Development and validation of RP-HPLC method for the estimation and separation of valsartan, losartan and irbesartan in bulk and pharmaceutical formulation. Int J Pharm Sci Rev Res 2014;24:311-4.

34. Czerwi Ska K, Mazurek AP. Identification and determination of selected angiotensin ii receptor antagonist group drugs by HPLC method. Acta Poloniae Pharm Drug Res 2011;68:831-7.
35. Goswami N. A validated a stability-indicating liquid chromatographic method for determination of process-related impurities and degradation behavior of irbesartan in solid oral dosage. J Adv Pharm Technol Res 2014;5:33-45.

36. Caudrona E, Laurenta S. Simultaneous determination of the acid/base antihypertensive drugs celiprolol, bisoprolol and irbesartan in human plasma by liquid chromatography. J Chromatogr B 2004;801:339-45.

37. Mhaske RA, Sahasrabudhe S, Mhaske AA. RP-HPLC method for simultaneous determination of Irbesartan, losartan, hydrochlorothiazide and chlorthalidone-application to commercially available drug products. Int J Pharm Sci Res 2012;3:1116-23.

38. Reddy R, Kumar GVS, Puranik SB. Development and validation of stability indicating reverse phase HPLC method for simultaneous estimation of irbesartan and hydrochlorothiazide in bulk drug and tablet dosage form. Int J Pharm Chem Biol Sci 2012;2:696-703.

39. Rane VP, Patil KR, Sangshetti JN. Stability indicating LC method for simultaneous determination of irbesartan and hydrochlorothiazide in pharmaceutical preparations. J Chromatogr Sci 2010;48:595-600.

40. Shanmugasundaram PS, Velraj M. Validated HPTLC method for simultaneous estimation of irbesartan and hydrochlorothiazide in a tablet dosage form. Pharm Chem 2011;3:310-7.

41. Shah H, Suhagia N, Shah B. Development and validation of a HPTLC method for the simultaneous estimation of irbesartan and hydrochlorothiazide in the tablet dosage form. Indian J Pharm Sci 2007;3:221-6.

42. Khodke AS, Laxman V, Mrinalini C. A validated stability indicating HPTLC method for simultaneous estimation of irbesartan and hydrochlorothiazide. Pharm Methods 2011;1:39-43.

43. Lara F, Maha F, Mamoun IA. Simultaneous determination of irbesartan and hydrochlorothiazide in human plasma using HPLC coupled with tandem mass spectrometry: application to bioequivalence studies. J Pharm Res 2010;3:251-66.

44. Tiwari HK, Monif T, Ranjan P. Quantitative estimation of irbesartan in two different matrices and its application to human and dog bioavailability studies using LC-MS/MS. Asian J Pharm Sci 2013;8:346-55.

45. Qiua X, Wangb Z, Wanga B. Simultaneous determination of irbesartan and hydrochlorothiazide inhuman plasma by ultrahigh performance liquid chromatography-tandem mass spectrometry and its application to bioequivalence study. J Chromatogr B 2014;957:110-5.

46. Bozala B, Dogan Topala B, Uslua B. Quantitative analysis of irbesartan in pharmaceuticals and human biological fluids by voltammetry. Anal Lett 2009;42:221-32.

47. Patel SK, Darji MS. Development and validation of reverse phase high-performance liquid chromatography method for simultaneous estimation of amlodipine besylate and irbesartan in synthetic mixture. Int J Pharm Drug Anal 2014;2:94-9.

48. Swamy GS, Kumar J, Rao S. A validated reverse phase HPLC method for the simultaneous estimation of irbesartan and amlodipine in pharmaceutical dosage form, World J Pharm Pharm Sci 2014;3:996-1007.

49. Kamala B, Jayathirtha RV, Sridhar S, Sankar DG. Stability indicating RP-HPLC studies for the estimation of irbesartan and amlodipine besylate in pharmaceutical formulations and identification and characterization of degradants using LC-MS. J Liq Chrom Relat Tech 2015;38:259-70.

50. ICH, Stability testing of new drug substances and products (Q1AR2), International Conference on Harmonization, IFPMA, Geneva; 2003.

51. FDA, Guidance R. Validation of chromatographic methods. Center for drug evaluation and research (CDER), Food Drug Administration; 1994. p. 2.

52. FDA, ORA validation and verification guidance for human drug analytical methods. Food and Drug Administration; 2003. p. 1. 